\title{
PERANCANGAN DAN PEMBUATAN ISLAMIC PORTAL DENGAN TEKNOLOGI ORACLE OBJECTS FOR OLE
}

\author{
Nur Wijayaning Rahayu ${ }^{1}$, Aris Tjahyanto ${ }^{2}$, Darlis Heru Murti² \\ ${ }^{1}$ Jurusan Teknik Informatika, Fakultas Teknologi Industri,Universitas Islam Indonesia \\ Jl. Kaliurang Km. 14 Yogyakarta 55501 \\ Telp. (0274) 895287 ext. 122, Faks. (0274) 895007 ext. 148 \\ 2Jurusan Teknik Informatika, Fakultas Teknologi Informasi, \\ Institut Teknologi Sepuluh Nopember, Surabaya \\ E-mail:nnur@fti.uii.ac.id
}

\begin{abstract}
ABSTRAK
Internet telah berkembang pesat dan memberikan kontribusi yang besar pada perkembangan ilmu pengetahuan. Tak terkecuali dalam bidang keagamaan, khususnya agama Islam. Banyak sekali layanan internet yang ditawarkan: pengetahuan agama, berita, forum diskusi, bahkan kajian format multimedia. Kesemuanya memberikan kontribusi yang positif bagi pengguna, meskipun admin harus mengelola data multimedia secara manual sehingga rawan terjadi inkonsistensi antara basis data dan tampilan aplikasi. Lebih jauh, inkonsistensi ini menyebabkan pengguna tidak bisa mendapatkan kenyamanan akses yang diharapkan. Dalam tugas akhir ini didesain dan diimplementasikan aplikasi basis data berbasis web dalam lingkungan Oracle9i dengan memanfaatkan teknologi OO4O (Oracle Objects for OLE) untuk menjamin konsistensi data. Aplikasi yang dibuat dinamakan ISPORT (ISlamic PORTal) yang menyediakan informasi berkaitan dengan agama Islam secara luas, meliputi kajian dan berita keislaman, gambar Al-Quran dan terjemahan masing-masing ayat, video pengetahuan Islam, dan forum diskusi. Aplikasi yang dibuat telah mengalami ujicoba fungsionalitas dan kinerja. Hasil uji coba fungsional menunjukkan bahwa aplikasi telah berfungsi sesuai dengan kebutuhan administrator dan pengguna aplikasi. Sedangkan dari uji coba kinerja menunjukkan bahwa aplikasi dapat diakses oleh banyak pengguna tanpa adanya penurunan kecepatan akses yang berarti.
\end{abstract}

Kata kunci: konsistensi, Oracle interMedia, OO4O

\section{PENDAHULUAN}

Dengan banyaknya jenis dan jumlah informasi yang didapatkan di internet, pengguna internet memiliki beragam pilihan sesuai dengan kebutuhan. Dan dengan memfokuskan satu format layanan tertentu pada satu aspek kehidupan, maka diharapkan pengguna akan mendapatkan layanan yang terbaik. Hal ini mencakup masalah content layanan, tampilan yang menarik, dan kemudahan akses. Tak terkecuali dalam bidang keagamaan, khususnya agama Islam, sebagai salah satu aspek kehidupan dasar manusia.

Jenis data yang dipakai di internet dibedakan menjadi dua, yaitu data biasa (teks) dan data rich-content (multimedia). Penempatan data jenis kedua secara 
statis dan semi-dinamis dengan metode standar akses database seperti ODBC (Open DataBase Connectivity) yang tidak bisa mengakses database secara langsung akan menyebabkan kecepatan akses menjadi lama dan memberi peluang terjadinya ketidakkonsistenan antara tampilan dan database. Kini, teknologi berbasis object untuk data multimedia yang dinamis telah diimplementasikan oleh Oracle dengan dukungan OO4O (Oracle Objects for OLE). OO4O adalah Oracle middleware yang bisa melakukan akses ke database Oracle secara langsung dari aplikasi pengguna dengan menggunakan standar Microsoft OLE (Object Linking and Embedding). Dalam hal ini, data multimedia disimpan dalam bentuk objek database, sehingga metode kerjanya lebih baik daripada ODBC, karena OO4O yang khusus bekerja pada database Oracle memberi keamanan lebih dan menyediakan dukungan penuh pada PL/SQL. Sehingga dari sisi server, teknologi ini mampu memudahkan administrator untuk mengelola data dan pengguna juga memperoleh data yang konsisten antara yang tersimpan pada database dan yang ditampilkan pada aplikasi klien.

Dengan dukungan teknologi ini, pembuatan portal yang berisi data multimedia dan fitur-fitur lain akan mampu memberikan manfaat yang terbaik kepada pengguna. Salah satunya adalah portal untik muslim ISPORT, yang mampu mengelola kedua jenis data tersebut di atas. ISPORT adalah ISlamic PORTal yang menyuguhkan pengetahuan agama Islam secara lengkap, ditunjang dengan database multimedia yang bisa diakses dengan metode $\mathrm{OO} 4 \mathrm{O}$.

\section{KONSEP ORACLE INTERMEDIA DAN OO4O}

Oracle interMedia merupakan perangkat lunak yang mempunyai fasilitas untuk menyimpan, mengelola dan menampilkan teks, dokumen, informasi lokasi geografis, dan data multimedia (Oracle Corporation, 1999) Oracle interMedia memungkinkan basis data Oracle untuk menyimpan, mengelola dan menampilkan data gambar (image), audio dan video sebagai satu kesatuan yang terintegrasi dengan isi basis data yang lain. Oracle interMedia meningkatkan kemampuan dan manajemen basis data Oracle, terutama yang berkaitan dengan isi multimedia di internet, perdagangan elektronik (electronic commerce) dan aplikasi berbasis multimedia.

Oracle interMedia menyediakan tipe objek dan method (ORDAudio, ORDDoc, ORDImage, ORDImageSignature, ORDVideo) untuk:

a. Pengelolaan media dan aplikasi metadata

b. Penyimpanan dan penampilan data

c. Pengaksesan data melalui antarmuka berbasis web maupun bukan dan memiliki kemampuan pencarian data dengan menggunakan data yang berelasi atau menggunakan spesial indeks.

Gambar 1 menunjukkan contoh objek ORDImage dalam sebuah tabel basis data.

48 Rahayu et al. - Perancangan dan Pembuatan Islamic Portal dengan Teknologi OO4O 


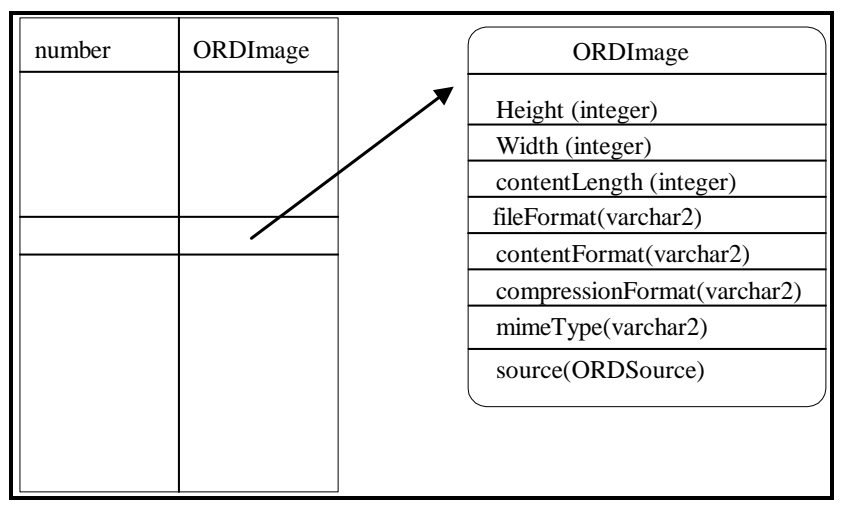

Gambar 1. Contoh objek ORDImage dalam sebuah tabel basis data

$\mathrm{OO} 4 \mathrm{O}$ adalah Oracle middleware yang didisain untuk mempermudah akses pada data yang tersimpan di basis data Oracle dengan bahasa pemrograman atau skrip apapun yang mendukung Microsoft COM Automation dan ActiveX technology.

Tidak seperti koneksi basis data API (Application Programming Interface) yang berbasis COM, seperti misalnya Microsoft ADO, OO4O Automation Server telah dikembangkan secara spesifik untuk digunakan pada server basis data Oracle. OO4O mengoptimasi API untuk mengakses fitur-fitur yang hanya khusus terdapat pada Oracle, yang mana fitur-fitur tersebut sulit atau tidak efisien jika diakses dengan komponen ODBC atau OLE DB.

OO4O juga memiliki fitur-fitur utama untuk mengakses basis data Oracle secara efisien pada berbagai lingkungan, mulai dari aplikasi 2-tier client/server (seperti pada Visual Basic atau Excel), sampai pada aplikasi yang digunakan pada lingkungan server aplikasi multi-tier, seperti aplikasi webserver pada Microsoft IIS (Internet Information Server), dan MTS (Microsoft Transaction Server).

\section{STUDI KEBUTUHAN}

Untuk merancang fitur-fitur Islamic Portal (selanjutnya disebut ISPORT), maka sebelumnya dilakukan analisis pada fitur-fitur situs Islam berbahasa Indonesia yang telah ada (lihat Tabel 1), terutama yang berkaitan dengan fitur layanan khusus portal dan data multimedia pada situs tersebut. Penelusuran fitur masing-masing situs kemudian dibandingkan untuk dijadikan acuan dalam membuat portal yang berfitur lengkap dan menggunakan teknologi baru dalam penyimpanan dan pengambilan data oleh para pengguna. 
Tabel 1. Perbandingan fitur beberapa situs berbahasa Indonesia

\begin{tabular}{|l|l|l|l|l|}
\hline Fitur & Alsofwah.or.id & Hidayatullah.com & Eramuslim.com & Assunnah.mine.nu \\
\hline Konten jenis & Artikel & $\begin{array}{l}\text { Berita dan } \\
\text { artikel }\end{array}$ & $\begin{array}{l}\text { Berita, } \\
\text { konsultasi, } \\
\text { artikel }\end{array}$ & $\begin{array}{l}\text { Kajian audio, dan } \\
\text { artikel }\end{array}$ \\
\hline Format & Teks & $\begin{array}{l}\text { Teks dan } \\
\text { gambar } \\
\text { penunjang. }\end{array}$ & $\begin{array}{l}\text { Teks dn } \\
\text { gambar } \\
\text { penunjang }\end{array}$ & Teks, file audio. \\
\hline Sumber & $\begin{array}{l}\text { - Pengelola } \\
\text { - Pengunjung }\end{array}$ & $\begin{array}{l}\text { - Pengelola } \\
\text { - Anggota }\end{array}$ & $\begin{array}{l}\text { - Pengelola } \\
\text { - Pengunjung }\end{array}$ & - Pengelola \\
\hline Jenis update & Tidak rutin & Rutin & Rutin & Tidak rutin \\
\hline $\begin{array}{l}\text { Informasi } \\
\text { update }\end{array}$ & $\begin{array}{l}\text { Ada, Newsletter } \\
\text { Buletin An-Nur }\end{array}$ & $\begin{array}{l}\text { Ada, Newsletter } \\
\text { Hidayatullah }\end{array}$ & Tidak ada & Tidak ada \\
\hline $\begin{array}{l}\text { Interaksi } \\
\text { antar } \\
\text { pengunjung }\end{array}$ & Buku tamu & Tidak ada & Tidak ada & Buku tamu \\
\hline $\begin{array}{l}\text { Antar } \\
\text { anggota }\end{array}$ & Tidak ada & Ada & Tidak ada & Tidak ada \\
\hline \begin{tabular}{l} 
Feedback \\
\hline
\end{tabular} & - Form feedback & - Form feedback & - Email kontak & - Email kontak \\
\hline
\end{tabular}

\section{PERANCANGAN ISPORT}

Dengan melihat fitur situs-situs yang telah ada dan perbandingan cara penyimpanan dan pengambilan data di internet, maka layanan ISPORT yang akan dibangun memiliki fitur-fitur sebagai berikut:

a. Jenis konten bervariasi: teks dan multimedia.

ISPORT mendukung beragam jenis konten, sehingga lebih banyak konten yang bisa ditampilkan. Jumlah data teks dan multimedia (gambar, audio, video) juga dibuat berimbang, sehingga pengguna bebas memilih konten sesuai dengan yang dikehendaki.

b. Sumber konten: pengelola dan anggota.

Selain di-upload oleh pengelola ISPORT, konten yang ada di dalamnya juga merupakan kiriman dari pengguna ISPORT yang telah mendaftar menjadi anggota. Pengiriman file (baik teks maupun multimedia) dilakukan setelah proses autentikasi (login). File yang masuk ke database berstatus pending, yaitu menunggu persetujuan dari pengelola. Hal ini dilakukan untuk mencegah masuknya artikel-artikel atau file-file yang tidak sesuai dengan tujuan pembuatan ISPORT.

c. Newsletter sesuai Preferensi Anggota.

Newsletter adalah informasi mengenai konten terbaru dari sebuah situs, yang dikirimkan kepada para anggota. Tidak seperti newsletter pada situs-situs yang lain yang berisi seluruh materi terbaru pada setiap periode update, maka newsletter pada ISPORT dibuat lebih spesifik. Para anggota bisa memilih kategorikategori konten yang dikehendaki sebagai isi dari newsletter. Misalnya ada anggota yang hanya ingin mendapatkan materi berita kegiatan terbaru, maka 
dengan adanya preferensi, newsletter yang ia dapatkan secara rutin hanya akan berisi kutipan berita-berita kegiatan terbaru, sehingga tidak akan terganggu dengan kategori-kategori lain yang tidak diminatinya.

d. Interaksi antar anggota dalam sebuah forum.

Forum interaksi antar anggota dimaksudkan sebagai wadah berbagi ilmu dan tukar informasi bagi para anggota. Forum dikelola oleh seorang moderator, yang bertugas memantau jalannya diskusi sehingga tidak menyimpang dari topik forum. Dan hanya para anggota yang bisa menggunakan fasilitas forum, sehingga diharapkan alur diskusi dapat dipertanggungjawabkan dengan adanya identitas yang jelas.

e. Penyimpanan data dilakukan secara dinamis.

Untuk mengoptimalkan kenyamanan pengguna dalam mengakses beragam jenis konten, maka dibutuhkan pula upaya untuk menyimpan data tersebut (teks maupun multimedia) secara dinamis. Konten disimpan dalam bentuk objek, sehingga ISPORT menggunakan teknologi Oracle interMedia dalam menyimpan beragam jenis konten ini.

f. Pengambilan data multimedia dengan teknologi streaming.

Teknologi streaming memungkinkan pengiriman data lebih cepat dan lebih mudah dinikmati daripada teknologi download yang telah umum pada situs-situs sekarang ini. Untuk itu, ISPORT menggunakan teknologi streaming dari Real Software dalam menyajikan konten jenis audio dan video. Untuk pengaksesan datanya sendiri, ISPORT menggunakan teknologi OO4O.

Untuk memenuhi fitur-fitur di atas, maka dirancanglah antarmuka seperti ditunjukkan pada Gambar 2.

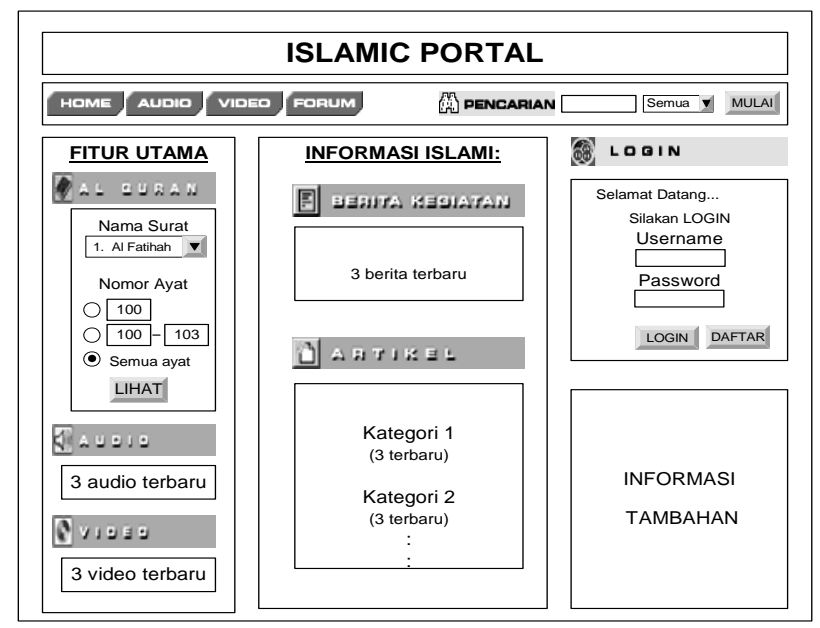

Gambar 2. Rancangan antarmuka halaman utama untuk pengunjung 
Setelah dilakukan perancangan antarmuka ini, maka dilakukan perancangan data dan proses dengan bantuan software Power Designer. Diagram rancangan pemodelan data ditunjukkan pada Gambar 3, sedangkan perancangan proses dengan DAD ditunjukkan pada Gambar 4.

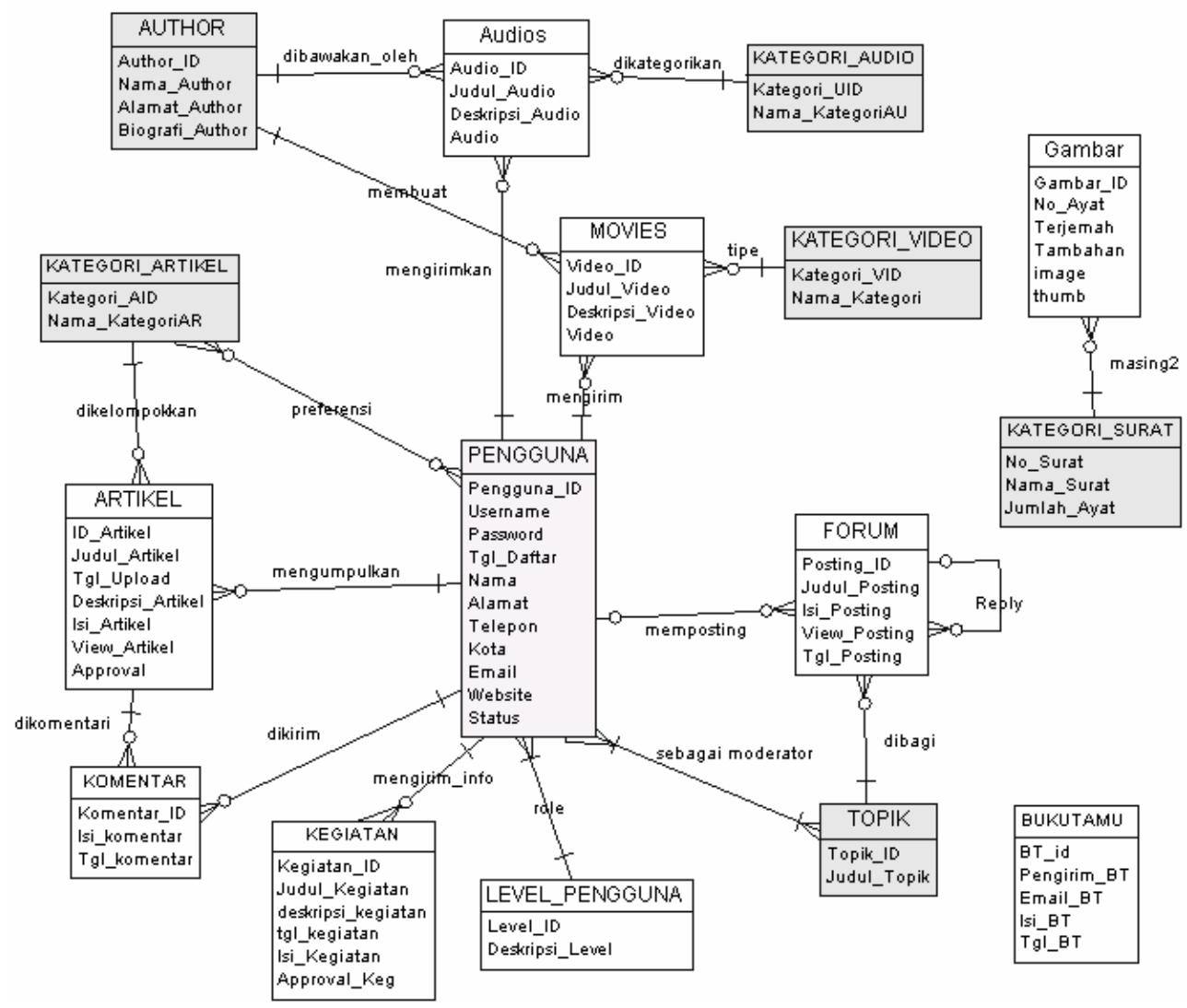

Gambar 3. Rancangan model data fisik

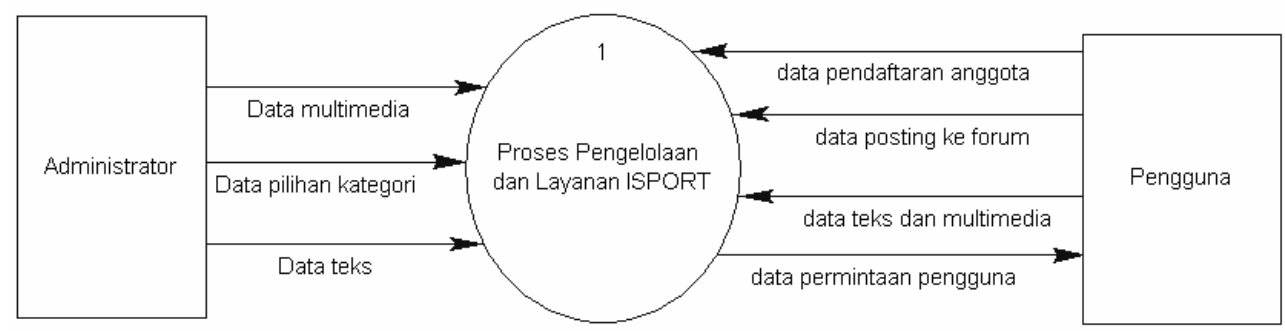

Gambar 4. Rancangan proses dengan DAD level 0

52 Rahayu et al. - Perancangan dan Pembuatan Islamic Portal dengan Teknologi OO4O 


\section{IMPLEMENTASI ISPORT}

berikut:

Contoh skrip ISPORT untuk pemasukan data gambar adalah sebagai

strImageInit = "ORDSYS. ORDIMAGE. init ( )"

strSQL = "INSERT INTO gambar ( gambar_id, no_surat, no_ayat, terjemah,

tambahan, image, thumb)

"VALUES ( gambar_sequence.nextval, :no_surat, :no_ayat, :terjemah :tambahan, "\& strImageInit \& ", " \& strImageInit \& ") RETURN gambar_id INTO : new_id "

Contoh tampilan antarmuka ditunjukkan pada Gambar 5.

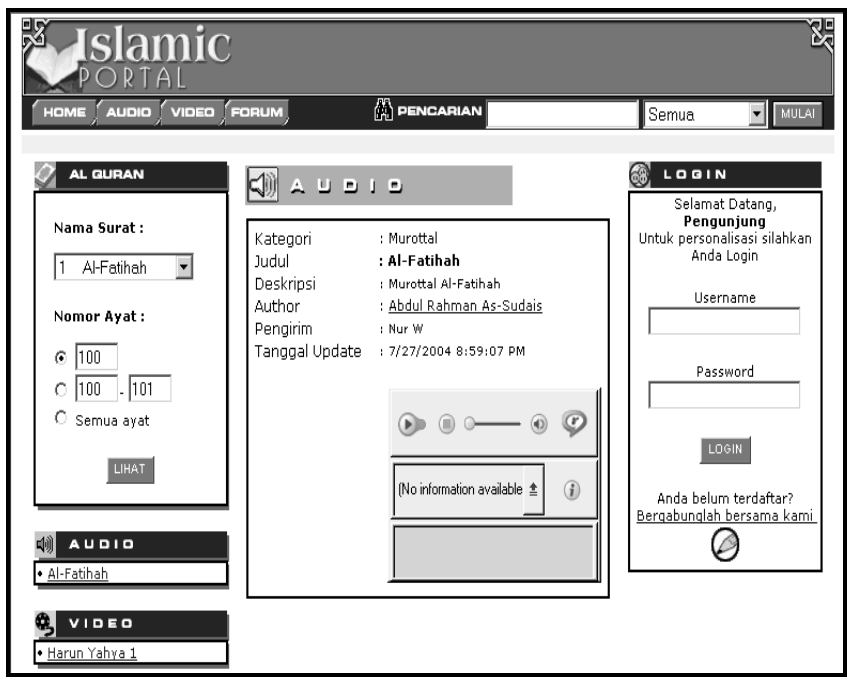

Gambar 5. Implementasi antarmuka halaman audio untuk pengunjung

\section{UJI COBA DAN ANALISIS}

Skenario uji coba ini merupakan rencana-rencana awal sebelum adanya pelaksanaan uji coba, sehingga pada skenario uji coba ini akan dibahas hal-hal atau permasalahan yang akan diujicobakan ke aplikasi ini.

Pada ujicoba level pengunjung, yang diujicobakan adalah:

a. Fitur penyediaan informasi teks dan multimedia (streaming)

b. Pendaftaran anggota

Tujuan skenario uji coba ini adalah:

a. Mengetahui kemampuan dan kecepatan dalam penyediaan informasi jika terjadi permintaan informasi yang cukup besar, terutama jika ada suatu informasi yang diminta oleh dua pengunjung atau lebih dalam waktu yang hampir bersamaan. Hal ini terutama difokuskan pada streaming data multimedia (audio, video, dan image) 
b. Mengecek validitas pendaftaran keanggotaan, terutama jika ada kesalahan pengunjung dalam pengisian data.

Sedangkan pada uji coba level anggota, selain fitur standar bagi pengunjung, fitur lain yang diujicobakan adalah:

a. Fitur pemasukan data teks dan multimedia

b. Setting preferensi dalam berlangganan newsletter

c. Cara posting dalam forum untuk berinteraksi dengan anggota yang lain.

Tujuan skenario ini adalah:

a. Mengetahui kecepatan dan validitas data yang dimasukkan, apabila ada dua anggota yang memasukkan data bersama-sama.

b. Mengecek validitas setting newsletter

c. Mengetahui efektivitas interaksi sesama anggota ISPORT dalam forum.

Terakhir, pada uji coba level administrator, hal yang diujicobakan adalah fitur pengelolaan data teks dan multimedia, yaitu berupa pemasukan dan approval (persetujuan) setiap data yang masuk dari anggota.

Tujuan uji coba ini adalah:

a. Mengecek inkonsistensi dalam mengelola data

b. Mengetahui ukuran dan kualitas dari data multimedia

Dari ujicoba yang dilakukan, didapat hasil sebagai berikut:

a. Untuk pengunjung, data teks tidak berpengaruh terhadap kecepatan. Dan pada proses buffering data multimedia tidak secepat jika yang membuka data video/audio hanya dua atau tiga pengunjung.

b. Untuk anggota, pemasukan data multimedia yang dilakukan oleh dua anggota atau lebih tidak menghasilkan permasalahan rumit.

c. Untuk administrator, didapat hasil bahwa data yang sama yang diubah dalam waktu yang hampir bersamaan menggunakan sistem queue, sehingga tidak terjadi masalah. Dan data multimedia yang disimpan pada basis data sedikitpun tidak berubah ukuran dan kualitasnya.

\section{KESIMPULAN DAN SARAN}

Berdasarkan hasil uji coba dan analisis dari aplikasi ISPORT ini, dapat diambil beberapa kesimpulan sebagai berikut:

a. ORDSYS sangat sesuai untuk digunakan sebagai penyimpanan data multimedia karena ukuran file multimedia yang disimpan akan persis sama dengan ukuran aslinya pada saat disimpan dalam basis data

b. Aplikasi yang dibuat dapat membantu pengunjung dalam mendapatkan informasi Islami.

c. Administrator dapat mengelola basis data dengan efektif dan efisien. Sehingga, konsistensi antara tampilan kepada pengunjung dan isi basis data dapat dioptimalkan.

d. Minimalisasi kesalahan memasukkan data informasi pada aplikasi

54 Rahayu et al. - Perancangan dan Pembuatan Islamic Portal dengan Teknologi OO4O 
Kemungkinan pengembangan Tugas Akhir ini yaitu:

a. Pengunaan tipe-tipe objek Oracle interMedia yang lain (ORDDoc dan ORDImageSignature).

b. Penambahan fitur-fitur portal yang lain.

\section{PUSTAKA}

Elmasri, R. (1999). Fundamentals of Database System. Edisi 3. New Jersey: Addison Wesley.

Bersinic, D. (2002). Oracle8iDBA: Architecture dan Administration Certification Bible. Hungry Minds Inc

Kroenky, D. M. (1997). Database Proccessing: Fundamentals, Design and Implementation. New York: Prentice-Hall.

Oracle Corporation. (1999). Oracle8i interMedia Audio, Image, and Video User's Guide and Reference. Diakses pada 17 Mei 2004 dari http://otn.oracle.com/doc.pdf /inter.815/a67299.pdf

Oracle Corporation. (2001). Intermedia Development Overview. Diakses pada 18 Mei 2004 dari http://otn.oracle.com/docs/products/oracle9i/doc_library/ release2/appdev.920/a88786.pdf

Real Networks Inc. (2003). Helix Universal Server Administration Guide Version 9.0. Diakses pada 3 Mei 2004 dari http:/ / document.real.com 